\title{
Algal diversity in relation to physical disturbance: a mosaic of successional stages in a subtidal cobble habitat
}

\author{
Andrew N. Davis \& Robert T. Wilce \\ Department of Botany, University of Massachusetts, Amherst, Massachusetts 01003, USA
}

\begin{abstract}
Effects of physical disturbance on algal diversity and composition were investigated in a subtidal cobble habitat at Plum Cove, Cape Ann, Massachusetts, USA. Monthly collections of cobbles with attached algae were made for 1 yr using SCUBA at 4 to $5 \mathrm{~m}$ below MLW. Cobbles were segregated into 4 size categories representing a gradient of disturbance frequency. Regression analyses were used to determine the relationship between cobble size and diversity and life-form of attached algae. Small cobbles (Category $1 ; 2 \mathrm{~cm}$ diam.), frequently disturbed (100\% chance of turnover $\mathrm{d}^{-1}$ ), are dominated by crustose algae and juvenile uprights and exhibit low diversity (5.77 species cobble ${ }^{-1}$; total 31 species). Category 2 cobbles ( $4.5 \mathrm{~cm}$ diam.), dominated by crustose algae and annual uprights, are disturbed less frequently $\left(10 \%\right.$ chance of turnover $\left.\mathrm{d}^{-1}\right)$ and have a higher diversity $(10.35$ species cobble $^{-1}$; total 46 species). Category 3 cobbles $(7 \mathrm{~cm}$ diam.), disturbed infrequently $(50 \%$ chance of turnover $\mathrm{mo}^{-1}$ ), exhibit the highest diversity (15.65 species cobble ${ }^{-1}$; total 56 species) with equal amounts of crustose algae, annual uprights, and perennial uprights. The largest cobbles (Category 4; $9.5 \mathrm{~cm}$ diam.), are the least disturbed $\left(10 \%\right.$ chance of turnover $\left.\mathrm{mo}^{-1}\right)$ and exhibit lower diversity than intermediate size cobbles ( 13.39 species cobble ${ }^{-1}$; total 37 species). These stable cobbles are dominated by perennial upright species, representing the climax condition in this habitat. The cobble habitat is a mosaic of successional stages with algal diversity and composition on each cobble determined by the frequency of disturbance. These patterns support the intermediate disturbancc hypothesis and suggcst that this community is maintained in a non-equilibrium state.
\end{abstract}

\section{INTRODUCTION}

Disturbance (physical or biological) has been recognized as a primary mechanism structuring a variety of terrestrial and marine communities (see review by Sousa 1984a). In particular, studies of coral reefs (Connell 1978), coral-associated decapod crustaceans (Abele 1976), rocky intertidal algal communities (Dayton 1975, Lubchenco \& Menge 1978), coral reef algal communities (Hay 1981), tropical rain forests (Strong 1977, Connell 1978), marine epifaunal invertebrates (Osman 1977), coral reef fish communities (Sale 1977 , Talbot et al. 1978), fossils of marine invertebrates on Ordovician cobbles (Wilson 1985), subtidal encrusting communities (Ayling 1981), and algal communities on intertidal boulders (Sousa 1979a), have demonstrated the role of disturbance in influencing local diversity and the development and maintenance of community structure. In these communities where the substratum is potentially limiting, disturbances (processes associ- ated with partial or total loss of biomass [Grime 1977]) create patches of free space that allow a diverse assemblage of organisms to coexist.

We have investigated the role of physical disturbance in influencing community dynamics of benthic algae in a subtidal cobble habitat. Few studies have examined the relationship between algal diversity and the stability of substrata in marine environments (Lieberman et al. 1979, 1984, Sousa 1979a). In this paper, we examine the role of physical disturbance (as predicted by the intermediate disturbance hypothesis) in influencing algal diversity and composition on different size cobbles. These results are discussed in relation to the ongoing debate regarding control of community structure. Our results support a non-equilibrium view through the maintenance of a patchy mosaic of successional stages (Davis \& Wilce 1984). Floristic and phenological data concerning the cobble algae are presented elsewhere (Davis \& Wilce 1987). 


\section{STUDY SITE}

The research was conducted at Plum Cove, a small bay located in Gloucester, Cape Ann, Massachusetts, USA (ca $70^{\circ} 40^{\prime} \mathrm{W}, 42^{\circ} 40^{\prime} 30^{\prime \prime} \mathrm{N}$ ) (Fig. 1A). At this site, the subtidal is characterized by granitic outcrops, sand, and cobbles (Fig. 1B). Skerries, small granitic rock islands partially exposed at low water, occur at the mouth of Plum Cove and offer some protection to the inner cove from heavy seas. A sand bottom extends into the subtidal from the shore to about $3 \mathrm{~m}$; patches of eelgrass Zostera marina L. occur in the less disturbed areas of this region. The flat cobble area occurs at 4 to $5 \mathrm{~m}$ below mean low water (MLW) between the inner bay and the outer skerries, and extends the width of the mouth of the cove (ca $115 \mathrm{~m}$ ). Cobbles range in size from $<1$ to $12 \mathrm{~cm}$ diameter and cover the underlying sediment. The cobble habitat has persisted for at least the past 2 decades (Wilce pers. obs.). Water temperature varies seasonally from $17^{\circ} \mathrm{C}$ in August to $1{ }^{\circ} \mathrm{C}$ in February. The study area is described in more detail elsewhere (Davis \& Wilce 1987).

\section{METHODS}

The relationship between cobble size and disturbance was determined as follows. Ten cobbles from each of 4 size categories $(2,4.5,7$, and $9.5 \mathrm{~cm}$ diam.; see Table 1 for other data concerning these size categories) were collected, cleaned, painted on one surface, and numbered by size category. The 40 cobbles were placed painted surface up in random order in a straight line between 2 metal stakes on the cobble bottom. Cobbles were visually checked after 1, 4, 24, 168 , and $720 \mathrm{~h}$, to determine the frequency of disturbance for each size category. Disturbance was measured by recording the number of cobbles in each size category that were either overturned (painted side down) or were displaced from their original positions.

Monthly collections (Nov 1981 to Oct 1982, except Jan) of cobbles with attached algae were made by SCUBA at 4 to $5 \mathrm{~m}$ below MLW. Collections were made from a $0.25 \mathrm{~m}^{2}$ quadrat placed at $1 \mathrm{~m}$ intervals on alternating sides of a $10 \mathrm{~m}$ transect. The transect was haphazardly placed in a different region of the cobble bottom each month. All cobbles within each quadrat were collected. Following each collection, a metal stake with a dated tag was driven into the bottom to prevent repetitive sampling and to allow subsequent examination of sampled sites to determine the extent of cobble movement into these cleared plots.

Cobble samples were segregated into the 4 size categories (using a fiberglass pattern with holes of 2 , $4.5,7$, and $9.5 \mathrm{~cm}$ diam.) and stored in $5 \%$ formalin in seawater. A degree of subjectivity was needed to size some cobbles owing to form irregularities, but the 4 size categories could easily be approximated. Ten cobbles $\mathrm{mo}^{-1}$ from 11 mo for each of the first 3 size categories were examined for quantitative analyses. Owing to the paucity of large cobbles, only 18 were available for these analyses. Thus, 348 cobbles with
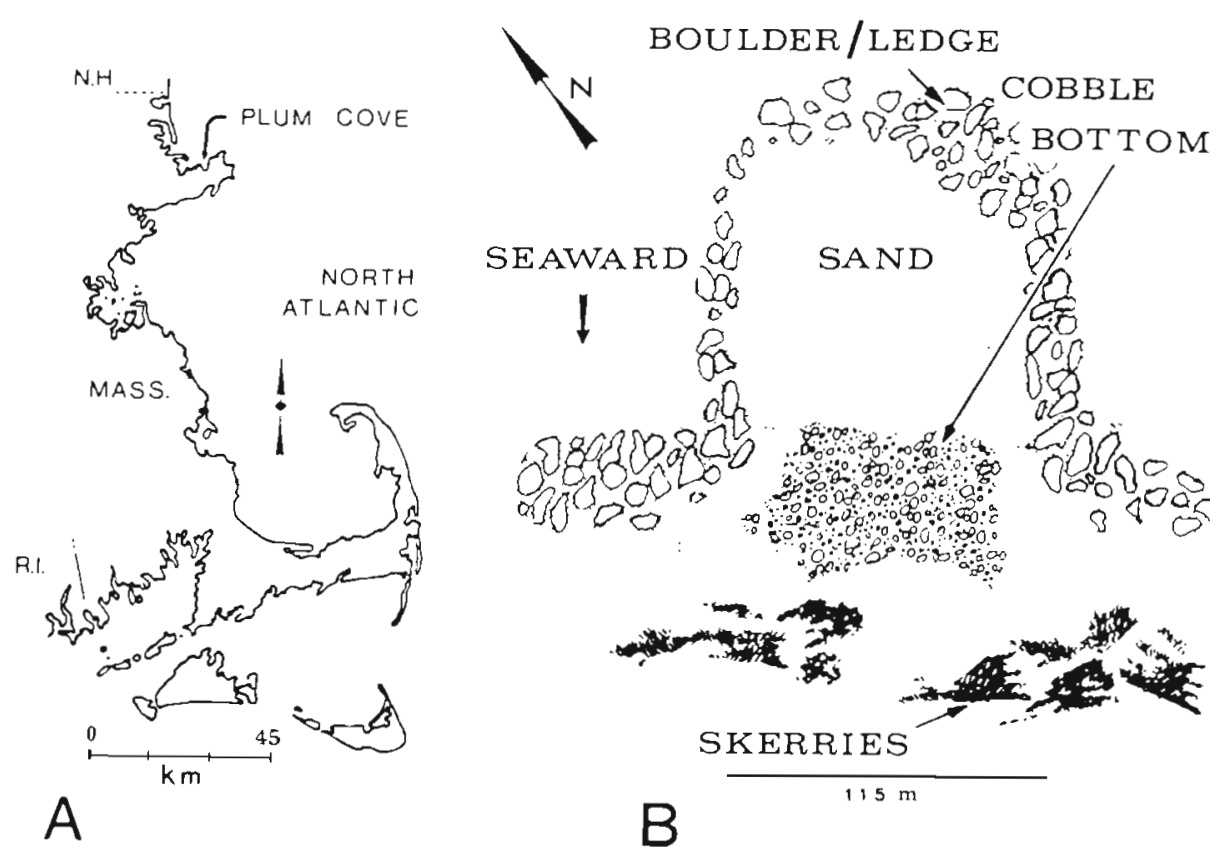

Fig. 1. (A) Map of Massachusetts (USA) coastline showing location of study site at Plum Cove, Cape Ann. (B) Sketch of Plum Cove study site 
attached algae were used in this study. All algae were identified and tallied as to occurrence and reproductive state; immature and non-reproductive individuals could not always be identified to species. The frequency of occurrence of a species was computed by dividing the number of cobbles on which it occurred by the total number of cobbles examined. Each frequency was multiplied by 100 to obtain percent frequency. The percent frequency of occurrence within each cobble size category and the overall percent frequency were determined for each species.

Regression analyses were used to determine the relationship between cobble size and diversity (defined as species-richness) and life-form of attached algae. Accurate measurement of percent cover or abundance for most of the algae, particularly crustose and turf algae, on cobbles was not possible. Thus, we believe that species richness is the most biologically applicable measure of diversity in this habitat (see also Peet 1974, May 1981, Levinton 1982). Regression analyses (Steel \& Torrie 1980) were done on the University of Massachusetts CYBER computer using the Harvey Program for Unequal Numbers (Harvey 1977, 1979).

\section{RESULTS}

\section{Cobble disturbance}

The results of the cobble disturbance experiment are presented in Table 1. It was determined that the froquency of disturbance is inversely proportional to cobble size. In situ observations also reveal stability differences between cobble size categories. Only cobbles in Categories 1 and 2 ( 2 and $4.5 \mathrm{~cm}$ diam., respectively) were observed rolling on the bottom, owing both to water movement and manipulation by hermit crabs Pagurus spp. In addition, monthly observations on previously sampled areas indicate that cobbles in Categories 1 and 2 moved into cleared areas most frequently, with Category 3 cobbles ( $7 \mathrm{~cm}$ diam.) less frequent. Category 4 cobbles $(9.5 \mathrm{~cm}$ diam.) were rarely found in sampled areas.

\section{Grazing}

The effects of physical disturbance appear to be naturally isolated from those of grazing in the cobble habitat (Davis \& Wilce 1987). Herbivores that are abundant on the nearby skerries are not common in the cobble habitat. (Mean densities of herbivores from 10 random $0.25 \mathrm{~m}^{2}$ quadrats taken on the cobble bottom are compared with 10 quadrats taken on the nearby skerries and are presented in Table 2.) Such reduced herbivore populations in unstable cobble habitats have been reported elsewhere (Lieberman et al. 1979, 1984, Littler \& Littler 1984, Steneck pers. comm.).

\section{Algal variation in the cobble habitat}

Qualitative observations indicate that algal coverage and maturation vary between cobble size categories. Complete algal coverage characterizes small cobbles (Categories 1 and 2), and lessens slightly through Category 3 cobbles. Category 4 cobbles are colonized only on upper surfaces and sides. Degree of algal maturation also varies between cobble size categories. Generally, upright species are not reproductive on cobbles in Categories 1 and 2; juvenile stages are common. Reproductive upright plants are common on cobbles in Categories 3 and 4 .

Percent frequencies of occurrence for the attached algae in relation to cobble size category are presented in Table 3. The percent frequency of occurrence for some crustose species is directly proportional to cobble size, although most occur with greatest frequency on Category 3 cobbles. Most upright species occur with greatest frequency on Category 3 cobbles, although a

Table 1. Determination of frequency of cobble disturbance for 4 size categories of cobbles over time. (Summer 1985 data)

\begin{tabular}{|c|c|c|c|c|c|}
\hline \multirow{2}{*}{$\begin{array}{l}\text { Cobble diam. and weight } \\
(\bar{X} \pm S D)\left(n=10 \text { category }^{-1}\right)\end{array}$} & \multicolumn{5}{|c|}{$\%$ cobbles disturbed over time } \\
\hline & $1 \mathrm{~h}$ & $4 \mathrm{~h}$ & $24 \mathrm{~h}$ & $168 \mathrm{~h}$ & $720 \mathrm{~h}$ \\
\hline $\begin{array}{l}\text { Category } 1 \text { : } \\
2 \mathrm{~cm} ; 5.75 \pm 1.44 \mathrm{~g}\end{array}$ & 70 & 90 & 100 & 100 & 100 \\
\hline $\begin{array}{l}\text { Category 2: } \\
4.5 \mathrm{~cm} ; 42.65 \pm 8.55 \mathrm{~g}\end{array}$ & 0 & 10 & 10 & 40 & 90 \\
\hline $\begin{array}{l}\text { Category 3: } \\
7 \mathrm{~cm} ; 143.95 \pm 35.53 \mathrm{~g}\end{array}$ & 0 & 0 & 0 & 0 & 50 \\
\hline $\begin{array}{l}\text { Category } 4: \\
9.5 \mathrm{~cm} ; 388.30 \pm 48.59 \mathrm{~g}\end{array}$ & 0 & 0 & 0 & 0 & 10 \\
\hline
\end{tabular}


Table 2. Comparison of herbivore densities on cobble bottom versus skerries. Herbivore identification and nomenclature follows that of Abbott (1974)

\begin{tabular}{|lcc|}
\hline Herbivore & $\begin{array}{c}\text { Mean no. ind 0.25 } \mathrm{m}^{-2} \text { quadrat } \\
\text { Cobble bottom } \\
(\mathrm{n}=10)\end{array}$ & $\begin{array}{c}\text { Skerries } \\
(\mathrm{n}=10)\end{array}$ \\
\hline $\begin{array}{l}\text { Acmaea testudinalis Müller } \\
\text { Littorina littorea Linnaeus }\end{array}$ & 1.9 & 6.7 \\
$\begin{array}{l}\text { Strongylocentrotus } \\
\text { droebachiensis Müller }\end{array}$ & 0.8 & 5.5 \\
$\begin{array}{l}\text { Tonicella marmorea } \\
\text { Fabricius }\end{array}$ & 0.0 & 4.7 \\
Tonicella rubra Linnaeus & 0.2 & 2.2 \\
\hline
\end{tabular}

number of perennial uprights are more common on Category 4 cobbles (e.g. Fucus distichus subspecies evanescens, Laminaria saccharina, Ceramium rubrum, Chondrus crispus, Corallina officinalis, Phyllophora sp., Polysiphonia flexicaulis, and Polysiphonia nigra).

Fig. 2 demonstrates the relation between cobble size category and algal diversity using 3 regression analyses: (1) number of species cobble ${ }^{-1}$ vs cobble size, (2) number of upright species cobble ${ }^{-1} v s$ cobble size, and (3) number of crustose species cobble ${ }^{-1}$ vs cobble size (refer to Fig. 2 legend for actual means and regression equations). The curves for Analysis $1(F=11.96)$ and

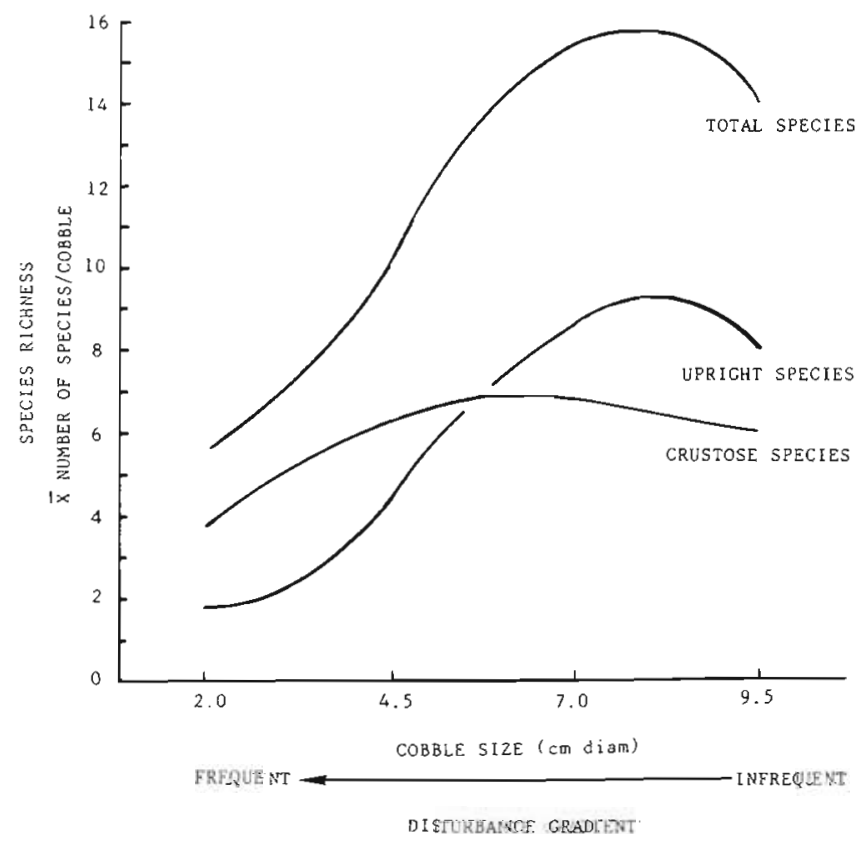

Fig. 2. Diversity and life-form of attached algae on different size cobbles at Plum Cove. Actual means for 2, 4.5, 7, and 9.5 $\mathrm{cm}$ diam. cobbles: total species $5.77,10.35,15.65,13.39$; upright species $1.93,4.53,8.67,7.17$; crustose species 3.84 , $5.82,6.98,6.22$. Regression equations: total species $\mathrm{S}$ (species richness) $=13.3944+5.6061 X-1.5413 X^{2}-1.2609 X^{3}$; upright species $S=6.8035+4.4099 X-0.8138 X^{2}-1.0577$

$\mathrm{X}^{3}$; crustose species $\mathrm{S}=6.8151+0.7213 \mathrm{X}-0.8383 \mathrm{X}^{2}$
Analysis $2(F=11.37)$ are based on cubic regressions that are highly significant $(\mathrm{p} \leq 0.01)$. The curve for Analysis 3 is based on a quadratic regression which is also highly significant $(\mathrm{F}=13.62 ; \mathrm{p} \leq 0.01)$; the cubic regression is not significant for this analysis. Note that for Analyses 1 and 2, the predicted means equal the actual means because the cubic regression incorporates the 3 treatment (cobble size categories) degrees of freedom into each analysis. The quadratic curve for Analysis 3 is based on predicted values that give the best-fitting curve to the actual means.

These results indicate that algal diversity peaks on Category 3 cobbles (Fig. 2; see legend for mean values). Mean number of species cobble ${ }^{-1}$ and number of upright species cobble ${ }^{-1}$ increase with increasing cobble size, reach a maximum on Category 3 cobbles, and then decrease significantly. The number of crustose species cobble ${ }^{-1}$ exhibits a similar pattern, although there is less variation between the 4 size categories as indicated by the shape of the curve. Thus, variation in diversity between cobble sizes is primarily due to changes in upright species diversity as the crustose species exhibit less variation with size as shown by the shape of the curves. Determination of species diversity on individual cobbles was not biased by the occurrence of juvenile states of several species. In these instances, taxon distinction was made in lieu of species identity.

Total species diversity vs cobble size category is shown in Fig. 3. Species are divided into 3 groups based on longevity and life-form: crustose, perennial uprights, and annual uprights. Category 3 cobbles ( $7 \mathrm{~cm}$ diam.) exhibit the highest total diversity (56 species), with an increase or decrease in cobble size showing a decline in diversity $(2 \mathrm{~cm}$ diam.: 31 species; $4.5 \mathrm{~cm}$ diam.: 46 species; $9.5 \mathrm{~cm}$ diam.: 37 species). Also meaningful is the distribution of the 3 groups over the 4 cobble categories. The smallest cobbles (Category 1) are characterized by a predominance of crustose species (45\%). Perennial and annual uprights occur mostly as juvenile forms. Category 2 cobbles are characterized by annual uprights (40\%) with equal amounts of crustose algae and perennial uprights. Category 3 cobbles exhibit relatively equal amounts of each group. The largest cobbles (Category 4) are characterized by a predominance of perennial uprights $(43 \%)$.

\section{DISCUSSION}

In hard-bottom marine communities where space is a limiting resource, disturbance plays an important role in preventing the monopoly of space by competitive dominants (Dayton 1971, Lubchenco \& Menge 1978, 
Table 3. Percent frequencies of occurrence of attached algae on cobble bottom at Plum Cove. Longevity is after Sears \& Wilce

(1975): A, annual; P, perennial. 'Crustose algae; J: juvenile (species determination not possible). Taxonomic authorities for all species are given in Davis \& Wilce (1987)

\begin{tabular}{|c|c|c|c|c|c|c|}
\hline \multirow[t]{2}{*}{ Algal species } & \multicolumn{6}{|c|}{ Cobble size (cm diam.) } \\
\hline & $\begin{array}{c}2 \\
(n=110)\end{array}$ & $\begin{array}{c}4.5 \\
(n=110)\end{array}$ & $\begin{array}{c}7 \\
(n=110)\end{array}$ & $\begin{array}{c}9.5 \\
(n=18)\end{array}$ & $\begin{array}{c}\text { Total } \\
(\mathrm{n}=348)\end{array}$ & Longevity \\
\hline \multicolumn{7}{|l|}{ CYANOPHYTA } \\
\hline 'Radaisia epiphytica & 9.0 & 27.3 & 42.7 & 44.4 & 27.3 & $?$ \\
\hline \multicolumn{7}{|l|}{ CHLOROPHYTA } \\
\hline Chaetomorpha aerea & 20.0 & 16.8 & 66.4 & 27.7 & 33.9 & $\mathrm{P}$ \\
\hline Chaetomorpha melagonium & 0.0 & 25.5 & 50.9 & 44.4 & 26.4 & $\mathrm{P}$ \\
\hline Cladophora sericea & 0.0 & 2.7 & 28.2 & 11.1 & 10.3 & $\mathrm{P}$ \\
\hline Enteromorpha spp. & 4.5 & 7.3 & 23.6 & 5.6 & 11.5 & A \\
\hline Monostroma pulchrum & 0.9 & 0.9 & 1.8 & 5.6 & 1.4 & A \\
\hline Ulva lactuca & 10.0 & 21.8 & 33.6 & 16.7 & 21.6 & A \\
\hline \multicolumn{7}{|l|}{ PHAEOPHYTA } \\
\hline Desmarestia aculeata & 0.0 & 0.0 & 1.8 & 0.0 & 0.6 & $\mathrm{P}$ \\
\hline Ectocarpus siliculosus & 15.5 & 29.1 & 44.5 & 27.8 & 29.6 & A \\
\hline Fucus distichus ssp. evanescens & 0.0 & 0.0 & 0.0 & 16.7 & 0.9 & $\mathrm{P}$ \\
\hline Fucus spp. (J) & 4.5 & 19.1 & 21.8 & 27.8 & 15.8 & $\mathrm{P}$ \\
\hline Giffordia ovata & 0.0 & 0.0 & 2.7 & 0.0 & 0.9 & A \\
\hline Laminaria saccharina & 0.0 & 0.0 & 0.0 & 33.3 & 1.7 & $\mathrm{P}$ \\
\hline Laminaria spp. (J) & 2.7 & 8.2 & 21.8 & 16.7 & 11.2 & $\mathrm{P}$ \\
\hline Leptonematella fasciculata & 2.7 & 10.9 & 16.4 & 11.1 & 10.1 & A \\
\hline Pilayella littoralis & 0.0 & 6.4 & 9.1 & 0.9 & 5.2 & A \\
\hline - Pseudolithoderma sp. & 6.4 & 4.5 & 6.4 & 0.0 & 4.5 & $P$ \\
\hline "Ralfsia borneti & 16.4 & 42.7 & 55.5 & 83.3 & 40.5 & $\mathrm{P}$ \\
\hline "Ralfsia clavata & 12.7 & 10.0 & 9.1 & 0.0 & 10.1 & $\mathrm{P}$ \\
\hline "Ralfsia spp. (J) & 15.5 & 44.5 & 34.5 & 22.2 & 31.0 & $\mathrm{P}$ \\
\hline 'Ralfsia fungiformis & 51.8 & 46.4 & 64.5 & 50.0 & 54.0 & $\mathrm{P}$ \\
\hline Scytosiphon/Petalonia (J) & 0.0 & 6.4 & 136 & 16.7 & 7.2 & A \\
\hline "Sorapion simulans & 12.7 & 5.5 & 18.2 & 0.0 & 11.5 & $\mathrm{P}$ \\
\hline Sphacelaria rigidula & 16.4 & 60.9 & 95.5 & 55.6 & 57.5 & $\mathrm{P}$ \\
\hline \multicolumn{7}{|l|}{ RHODOPHYTA } \\
\hline Ahnfeltia plicata & 54.5 & 73.6 & 90.0 & 88.9 & 73.6 & $\mathrm{P}$ \\
\hline Ceramium rubrum & 0.9 & 2.7 & 7.3 & 16.7 & 4.6 & $\mathrm{P}$ \\
\hline Chondrus crispus & 0.0 & 0.0 & 0.0 & 11.1 & 0.6 & $\mathrm{P}$ \\
\hline - Clathromorphum circumscriptum & 53.6 & 85.5 & 92.7 & 100.0 & 78.4 & $\mathrm{P}$ \\
\hline Corallina officinalis & 4.5 & 3.6 & 6.4 & 27.8 & 6.0 & $\mathbf{P}$ \\
\hline Cystoclonium purpureum & 0.0 & 0.0 & 1.8 & 0.0 & 0.6 & $P$ \\
\hline Dumontia contorta & 17.3 & 55.5 & 92.7 & 72.2 & 56.0 & AP \\
\hline "Hildenbrandia rubra & 10.0 & 9.1 & 24.5 & 11.1 & 14.4 & $\mathrm{P}$ \\
\hline - Lithothamnium glaciale & 3.6 & 13.6 & 11.8 & 16.7 & 10.1 & $\mathrm{P}$ \\
\hline - Petrocelis sp. & 33.6 & 80.0 & 92.7 & 88.9 & 69.8 & $\mathrm{P}$ \\
\hline Phyllophora sp. & 18.2 & 40.1 & 80.0 & 83.3 & 48.3 & $\mathrm{P}$ \\
\hline - Phymatolithon laevigatum & 2.7 & 4.5 & 13.6 & 5.6 & 6.9 & $\mathrm{P}$ \\
\hline Platoma bairdii & 0.0 & 0.0 & 1.8 & 0.0 & 0.6 & A \\
\hline Polysiphonia flexicaulis & 0.0 & 0.0 & 2.7 & 11.1 & 1.4 & $\mathrm{P}$ \\
\hline Polysiphonia harveyi & 0.0 & 0.0 & 1.8 & 16.7 & 1.4 & A \\
\hline Polysiphonia nigra & 0.0 & 5.5 & 1.8 & 11.1 & 2.9 & $P$ \\
\hline Polysiphonia nigrescens & 0.0 & 0.0 & 3.6 & 0.0 & 1.1 & $P$ \\
\hline Polysiphonia urceolata & 3.6 & 31.8 & 79.1 & 44.4 & 38.5 & A \\
\hline Porphyra spp. & 0.0 & 0.9 & 4.5 & 0.0 & 1.7 & A \\
\hline "Porphyrodiscus simulans & 59.1 & 86.4 & 96.4 & 94.4 & 81.3 & $\mathrm{P}$ \\
\hline Rhodomela confervoides & 2.7 & 12.7 & 39.1 & 27.8 & 18.7 & $\mathrm{P}$ \\
\hline - Rhodophysema elegans & 60.0 & 64.5 & 80.0 & 50.0 & 67.2 & $\mathrm{P}$ \\
\hline Spernothamnion repens & 5.5 & 30.0 & 34.5 & 33.3 & 23.9 & $\mathrm{P}$ \\
\hline
\end{tabular}




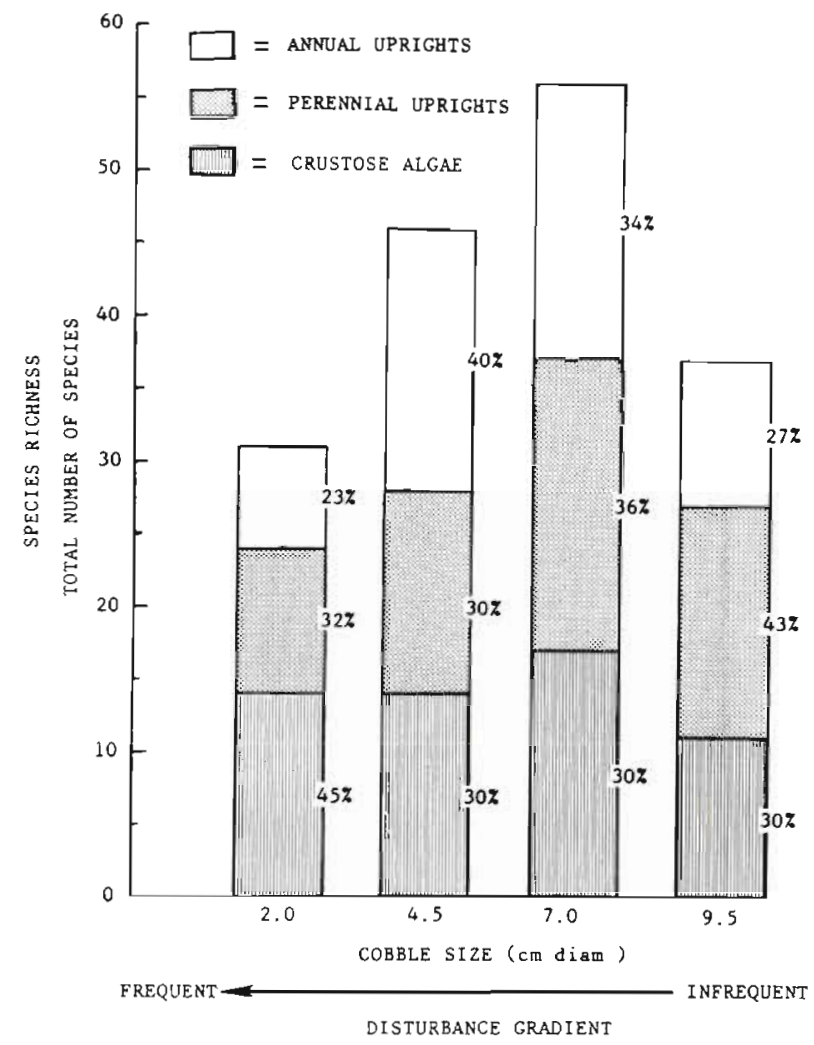

Fig. 3. Total species diversity versus cobble size at Plum Cove. Data are also presented as the number of species within each longevity group (as a percentage of total species) for each cobble size

Ayling 1981, Sebens 1985). Thus, disturbance by physical or biological factors is important in providing space for colonization by opportunistic species and in maintaining a high diversity assemblage. The structure of the Plum Cove cobble bottom algal community can be interpreted to be, to a large extent, a consequence of physical disturbance. The results of this study indicate that the frequency of cobble disturbance affects algal species diversity and composition by determining the time interval over which successional species replacements can occur.

The main sources of disturbance in the shallow subtidal at Plum cove are tidal exchanges, currents, and periodic storms of sufficient force to cause cobble turnover. Cobble disturbance can create free patches of space through the elimination of algal species by abrasion. Other studies have shown an inverse relation between the frequency of disturbance and rock size similar to that reported here (Riedl 1964, Osman 1977, Lieberman et al. 1979, Sousa 1979a, McAuliffe 1984). In addition, Sousa (1979a) determined that it is the frequency with which a rock is disturbed, rather than simply its size (surface area), that is responsible for different patterns in species composition and diversity on rocks of differing stability.
The disturbed Plum Cove cobbles are dominated by crustose algae and turf-forms that are adapted to physically or biologically disturbed environments (Sears \& Wilce 1975, Littler 1980, Littler \& Littler 1980, 1983, 1984, Ayling 1981, Dethier 1981, Hay 1981, Hagen 1983). In general, when rates of disturbance are high, species that are slow to grow or recruit new individuals may be prevented from establishing themselves (Sebens 1985). Typically, opportunistic species persist in such habitats (Dayton 1975, Sears \& Wilce 1975, Murray \& Littler 1978, Lieberman et al. 1979, 1984, Sousa 1979a, b, 1980, Dethier 1981, Taylor \& Littler 1982). However, species able to resist disturbance, such as crustose algae, can also dominate the substratum (Ayling 1981). Thus, although crustose algae are slow growing, their abrasion-resistant morphology allows them to dominate space in disturbed environments. As noted previously (Davis \& Wilce 1987), the crustose algae in the cobble habitat do not conform to functional-form models as presented (Littler 1980, Littler \& Littler 1980, 1984). The ecology of crustose and turf algae on the cobble bottom is currently being investigated in more detail.

The results presented here are a subtidal extension of Sousa's (1979a) findings that algal species composition and diversity on intertidal boulders change along a gradient of substratum size in relation to disturbance. At Plum Cove, the smallest cobbles (Category 1), with frequent disturbances, exhibit low diversity and support a flora of primarily abrasion-resistant crustose algae, and few juvenile uprights. Category 2 cobbles are slightly more diverse with a greater number of annual uprights, suggesting that these species grow rapidly and reproduce during short periods between disturbances. Short-lived annual species, many with heteromorphic life histories involving an abrasionresistant crustose phase, are common in other unstable cobble habitats (Hawkes 1982, Maggs 1985, Maggs \& Guiry 1985). Similarly, Waern (1958) believed that the unstable Gasö shell bottom (southwest coast of Sweden) was a refuge for weakly competitive fugitive species. Cobbles subjected to intermediate frequencies of disturbance (Category 3) are floristically the most diverse. It appears these cobbles are disturbed frequently enough to prevent full development of competitively superior leathery or bushy species, while at the same time allowing other species to coexist. The largest cobbles (Category 4), infrequently disturbed, exhibit low diversity and are dominated by large perennial canopy species that resemble the vegetation of the nearby stable rock skerries.

We suggest that differences in species richness between cobble size categories are the results of differential removal of upright species generated by physical disturbance. The occurrence of many of the same 
upright species on all cobble sizes, differing only in maturation states, suggests that differential elimination occurs rather than differential settling (germination) (Lieberman et al. 1979). In other words, the probability of removal of an upright species from a small cobble is greater than from a large cobble.

These results conform to the intermediate disturbance hypothesis that suggests that local diversity is maximized at some intermediate scale of disturbance (biological or physical), and that the optimum varies with physical environment and type of community under consideration. This idea was first proposed by Paine \& Vadas (1969) and later expanded on by others whose results indicate a similar response of species richness to varying levels of physical or biological disturbance (Osman 1977, Connell 1978, Lubchenco 1978, Sousa 1979a, Denslow 1980, Ayling 1981, Carpenter 1981, Lubchenco \& Gaines 1981, Hixon \& Brostoff 1983, Menge et al. 1985, Wilson 1985). Since the cobble sizes represent a gradient of disturbance frequency, the optimum frequency of disturbance for this algal community was that affecting Category 3 cobbles. An increase in disturbance (smaller cobbles) or a decrease in disturbance (larger cobbles), results in a significant decline in diversity.

The patchwork of space generated by disturbance and available for colonization maintains a community of sessile organisms as a perpetual preclimax mosaic (Dayton 1971, Strong 1977, Lieberman et al. 1979, 1984, Sousa 1979a, b, 1980, 1984a, b, Denslow 1980, Dethier 1984, Littler \& Littler 1984). Both spatial and temporal heterogeneity in disturbance result in a mosaic of successional stages in the cobble habitat; each cobble may be at a different stage of succession depending upon the time of last disturbance and the correlation of that disturbance with species life-history strategies and reproductive periodicities (Dayton 1975, Sousa 1979b, 1980, 1984b, Dethier 1984). At Plum Cove, cobble Categories 1 to 3 represent different preclimax states; the largest cobbles (Category 4) represent the climax situation.

Evidence from several studies of natural communities supports a non-equilibrium view of community structure (Dayton 1971, 1975, Dayton \& Hessler 1972, Abele 1976, Osman 1977, Sale 1977, Strong 1977, Connell 1978, Lubchenco \& Menge 1978, Murray \& Littler 1978, Talbot et al. 1978, Lieberman et al. 1979, Sousa 1979a, b, 1980, Ayling 1981, Paine \& Levin 1981, McAuliffe 1984). In agreement with these studies, the results presented here suggest that high diversity is maintained in a non-equilibrium state by a balance of processes (disturbance and competition). Recurring disturbances prevent the exclusion of weakly competitive opportunistic species and keep diversity high (Category 3). In the absence of disturbance (Category
4), the assemblage of species progresses toward an equilibrium state in which the process of successional replacement may lead to the dominance of competitive, perennial species that outcompete early colonizers and tends to lower diversity. Dayton (1971) noted that the removal of biological disturbance also resulted in a cover of climax algal species. Thus, it appears that patterns in community structure and development are independent of the processes that act as agents of disturbance. Biological disturbance is replaced by physical disturbance in cobble habitats but the resultant patterns in community structure are similar.

In summary, the cobble habitat is a mosaic of successional stages; algal diversity and composition is correlated with cobble size in relation to the frequency of physical disturbance. High diversity is maintained in a non-equilibrium state as predicted by the intermediate disturbance hypothesis, and in the absence of disturbance, diversity declines. This study emphasizes that physical disturbance plays a major role in structuring this subtidal algal community and contributes to our understanding of community dynamics in other marine and terrestrial habitats.

Acknowledgements. This paper represents a portion of the Ph. D. dissertation submitted by A. N. D. to the Department of Botany, University of Massachusetts, Amherst. Timothy Briggs, Edward Davis, William Dennison, Craig Edwards, Paul Godfrey, Steven Miller, Marshall Pregnall, Seymour Shapiro, Robert Steneck, Robert Vadas, and Charles Yarish provided comments which substantially improved the manuscript. Special thanks go to Richard Damon for his invaluable help with the experimental design and statistical analyses. A. N. D. is grateful to $\Upsilon$. Briggs, Alan Stewart, Jeffrey Einarson Jeffrey West, and Howard Levine for their diving assistance. Robert Bullock kindly assisted with the chiton identifications. We acknowledge Herbert Hultin (Director) and the staff of the University of Massachusetts Marine Station for their cooperation and use of the facilities. This work was supported in part by an Albert L. Delisle Scholarship and a Sigma Xi Grant in Aid of Research awarded to A. N. D.

\section{LITERATURE CITED}

Abbott, R. T. (1974). American seashells, 2nd edn. Van Nostrand Reinhold Co., New York

Abele, L. G. (1976). Comparative species richness in fluctuating and constant environments: coral-associated decapod crustaceans. Science 192: 461-463

Ayling, A. M. (1981). The role of biological disturbance in temperate subtidal encrusting communities. Ecology 62: 830-847

Carpenter, R. C. (1981). Grazing by Diadema antillarum (Philippi) and its effects on the benthic algal community. J. mar. Res. 39: 749-765

Connell, J. H. (1978). Diversity in tropical rain forests and coral reefs. Science 199: 1302-1310

Davis, A. N., Wilce, R. T. (1984). Ecology of the sublittoral marine algae from a cobble bottom: new evidence for the non-equilibrium view of community structure. Br. phycol. J. 19: 192 
Davis, A. N., Wilce, R. T. (1987). Floristics, phenology, and ecology of the sublittoral manine algae in a cobble habitat (Plum Cove, Cape Ann, Massachusetts, USA). Phycologia 26: in press

Dayton, P. K. (1971). Competition, disturbance, and community organization: the provision and subsequent utilization of space in a rocky intertidal community. Ecol. Monogr. 41 351-389

Dayton, P. K. (1975). Experimental evaluation of ecological dominance in a rocky intertidal algal community. Ecol. Monogr. 45: 137-159

Dayton, P. K., Hessler, R. R. (1972). Role of biological disturbance in maintaining diversity of the deep sea. Deep Sea Res. 19: 199-208

Denslow, J. S. (1980). Patterns of plant species diversity during succession under different disturbance regimes. Oecologia 46: 18-21

Dethier, M. N. (1981). Heteromorphic algal life histories: the seasonal pattern and response to herbivory of the brown crust, Ralfsia californica. Oecologia 49: 333-339

Dethier, M. N. (1984). Disturbance and recovery in intertidal pools: maintenance of mosaic pattern. Ecol. Monogr. 54: 99-118

Grime, J. P. (1977). Evidence for the existence of three primary strategies in plants and its relevance to ecological and evolutionary theory. An. Nat. 111: 1169-1194

Hagen, N. T. (1983). Destructive grazing of kelp beds by sea urchins in Vestfjorden, northem Norway. Sarsia 68: $177-190$

Harvey, W. R. (1977). User's guide to LSML76. Ohio State University, Columbus, Ohio

Harvey, W. R. (1979). Least-squares analysis of data with unequal subclass numbers. United States Department of Agriculture, Science and Education Administration, Beltsville, Maryland

Hawkes, M. W. (1982). Schmitzia evanescens sp. nov. (Rhodophyta, Gigartinales): a new species of Calosiphoniaceae from the northeastern New Zealand coast. J. Phycol. 18: 368-378

Hay, M. E. (1981). The functional morphology of turf-forming seaweeds: persistence in stressful marine habitats. Ecology 62: 739-750

Hixon, M. A., Brostoff, W. N. (1983). Damselfish as keystone species in reverse: intermediate disturbance and diversity of reef algae. Science 220: 511-513

Levinton, J. S. (1982). Marine ecology. Prentice-Hall, Englewood Cliffs, New Jersey

Lieberman, M., John, D. M., Lieberman, D. (1979). Ecology of subtidal algae on seasonally devastated cobble substrates off Ghana. Ecology 60: 1151-1161

Lieberman, M., John, D. M., Lieberman, D. (1984). Factors influencing algal species assemblages on reef and cobble substrata off Ghana. J. exp. mar. Biol. Ecol. 75: 129-143

Littler, M. M. (1980). Morphological form and photosynthetic performances of marine macroalgae: test of a functional/ form hypothesis. Botanica mar. 22: 161-165

Littler, M. M., Littler, D. S. (1980). The evolution of thallus form and survival strategies in benthic marine macroalgae: field and laboratory tests of a functional form model. Am. Nat. 116: 25-44

Littler, M. M., Littler, D. S. (1983). Heteromorphic life-history strategies in the brown alga Scytosiphon lomentaria (Lyngb.) Link. J. Phycol. 19: 425-431

Littler, M. M., Littler, D. S. (1984). Relationships between macroalgal functional form groups and substrata stability in a subtropical rocky-intertidal system. J. exp. mar. Biol. Ecol. 74: 13-34
Lubchenco, J. (1978). Plant species diversity in a marine intertidal community: importance of herbivore food preference and algal competitive abilities. Am. Nat. 112: 23-39

Lubchenco, J., Gaines, S. D. (1981). A unified approach to marine plant-herbivore interactions. I. Populations and communities. A. Rev. Ecol. Syst. 12: 405-437

Lubchenco, J., Menge, B. A. (1978). Community development and persistence in a low rocky intertidal zone. Ecol. Monogr. 59: 67-94

McAuliffe, J. R. (1984). Competition for space, disturbance, and the structure of a benthic stream community. Ecology 65: 894-908

Maggs, C. A. (1985). The life history of Erythrodermis allenii (Rhodophyta: Phyllophoraceae). Br. phycol. J. 20: 189

Maggs, C. A., Guiry, M. D. (1985). Life history and reproduction of Schmitzia hiscockiana sp. nov. (Rhodophyta, Gigartinales) from the British Isles. Phycologia 24: 297-310

May, R. M. (1981). Theoretical ecology: principles and applications, 2nd edn. Sinauer Associates, Sunderland, Massachusetts

Menge, B. A., Lubchenco, J., Ashkenas, L. R. (1985). Diversity, heterogeneity and consumer pressure in a tropical rocky intertidal community. Oecologia 65: 394-405

Murray, S. N., Littler, M. M. (1978). Patterns of algal succession in a perturbated marine intertidal community. J. Phycol. 14: 506-512

Osman, R. W. (1977). The establishment and development of a marine epifaunal community. Ecol. Monogr. 47: 37-63

Paine, R. T., Levin, S. A. (1981). Intertidal landscapes: disturbance and the dynamics of pattern. Ecol. Monogr. 51 $145-178$

Paine, A. T., Vadas, R. L. (1969). The effects of grazing by sea urchins, Strongylocentrotus spp., on benthic algal populations. Limnol. Oceanogr. 14: 710-719

Peet, R. K. (1974). The measurement of species diversity. A Rev. Ecol. Syst. 5: 285-308

Riedl, R. (1964). Die Erscheinungen der Wasserbewegung und ihre Wirkung auf Sedentarier im mediterranean Felslitoral. Helgoländer wiss. Meeresunters. 10: 155-186

Sale, P. F. (1977). Maintenance of high diversity in coral reef fish communities. Am. Nat. 111: 337-359

Sears, J. R., Wilce, R. T. (1975). Sublittoral, benthic marine algae of southern Cape Cod and adjacent islands: seasonal periodicity, associations, diversity and floristic composition. Ecol. Monogr. 45: 337-365

Sebens, K. P. (1985). The ecology of the rocky subtidal zone. Am. Sci. 73: 548-557

Sousa, W. P. (1979a). Disturbance in marine intertidal boulder fields: the non-equilibrium maintenance of species diversity. Ecology 60: 1225-1239

Sousa, W. P. (1979b). Experimental investigations of disturbance and ecological succession in a rocky intertidal algal community. Ecol. Monogr. 49: 227-254

Sousa, W. P. (1980). The responses of a community to disturbance: the importance of successional age and species' Life histories. Oecologia 45: 72-81

Sousa, W. P. (1984a). The role of disturbance in natural communities. A. Rev. Ecol. Syst. 15: 353-391

Sousa, W. P. (1984b). Intertidal mosaics: patch size, propagule availability, and spatially variable patterns of succession. Ecology 65: 1918-1935

Steel, R. G. D., Torrie, J. H. (1980). Principles and procedures of statistics. McGraw-Hill, New York

Strong, D. R. (1977). Epiphyte loads, tree falls, and perennial forest disruption: a mechanism for maintaining higher 
tree species richness in the tropics without animals. J. Biogeogr. 4: 215-218

Talbot, F. H., Russell, B. C., Anderson, G. R. V. (1978). Coral reef fish communities: unstable, high-diversity systems? Ecol. Monogr. 48: 425-440

Taylor, P. R., Littler, M. M. (1982). The roles of compensatory mortality, physical disturbance, and substrate retention in the development and organization of a sand-influenced, rocky intertidal community. Ecology 63: 135-146

Waern, M. (1958). Phycological investigations of the Swedish west coast. 1. Introduction and study of the Gaso, shell bottom. Svensk Bot. Tidskr. 52: 319-342

Wilson, M. A. (1985). Disturbance and ecologic succession in an upper Ordovician cobble-dwelling hardground fauna. Science 228: 575-577

This article was presented by Professor J. G. Field; it was accepted for printing on February 19, 1987 